Györgyi Horváth, Béla Kocsis, Éva Lemberkovics, Andrea Böszörményi, Péter G. Ott És Ágnes M. Móricz: Detection of antibacterial activity of essential oil components by TLC-bioautography using luminescent bacteria. Journal of Planar Chromatography Modern TLC 26 (2013) 114-118. DOI: 10.1556/JPC.26.2013.2.2

http://akademiai.com/content/r75j5mjxx76j8872/?p=ae95405df38e4934900f76b003b34 $4 \mathrm{c} 0 \& \mathrm{pi}=2$

\title{
Detection of antibacterial activity of essential oil components by TLC- bioautography using luminescent bacteria
}

Györgyi Horváth*, Béla Kocsis, Éva Lemberkovics, Andrea Böszörményi, Péter G. Ott, and Ágnes M. Móricz

${ }^{\star}$ Correspondence author: gyorgyi.horvath@aok.pte.hu

Gy. Horváth: Department of Pharmacognosy, Medical School, University of Pécs, Rókus u. 2., H-7624 Pécs, Hungary

B. Kocsis: Institute of Medical Microbiology and Immunology, Medical School, University of Pécs, Szigeti út 12., H-7624 Pécs, Hungary

É. Lemberkovics and A. Böszörményi: Institute of Pharmacognosy, Faculty of Pharmacy, Semmelweis University, Üllöi út 26., H-1085 Budapest, Hungary

P.G. Ott and Á.M. Móricz: Plant Protection Institute, Centre for Agricultural Research, Hungarian Academy of Sciences, Herman Ottó Str. 15., H-1022 Budapest, Hungary

Key words: thin layer chromatography, gas chromatography, direct bioautography, essential oil, luminescent bacteria 


\section{Summary}

The aim of the present study was the chemical characterization of some medically relevant essential oils (tea tree, clove, cinnamon bark, thyme and eucalyptus) and the investigation of antibacterial effect of the components of these oils by use of a direct bioautographic method. Thin layer chromatography (TLC) was combined with biological detection in this process. The chemical composition of the oils was determined by gas chromatography (GC) and gas chromatography-mass spectrometry (GC-MS). Eucalyptol (84.2\%) was the main component of the essential oil of eucalyptus, eugenol $(83.7 \%)$ of clove oil, and trans-cinnamic aldehyde $(73.2 \%)$, thymol $(49.9 \%)$ and terpinen-4-ol $(45.8 \%)$ of cinnamon bark, thyme and tea tree oils, respectively. Antibacterial activity of the separated components of these oils, as well as their pure main components (eucalyptol, eugenol, trans-cinnamic aldehyde and thymol) was observed against the Gram-negative luminescence tagged plant pathogenic bacterium Pseudomonas syringae pv. maculicola (Psmlux) and the Gram-negative, naturally luminescent marine bacterium Vibrio fischeri. On the whole, the antibacterial activity of the essential oils could be related to their main components, but the minor constituents may be involved in this process. Trans-cinnamic aldehyde and eugenol were the most active compounds in TLC-bioautography.

The sensitivity of TLC-bioautographic method can be improved with using luminescent test bacteria. This method is more cost-effective and provides more reliable results in comparison with conventional microbiological methods, e.g. disc-diffusion technique. 


\section{Introduction}

Essential oils are complex mixtures of volatile compounds produced by living organisms and isolated by pressing or distillation from a whole plant or plant part of known taxonomic origin. They are very interesting natural products and among other qualities they possess various biological properties. An essential oil may have hundreds of individual chemical components; most of them, e.g. thymol, eugenol, 1,8-cineole, have characteristic smell and may have biological activity. Without doubt the antimicrobial activity is one of the most relevant property of the essential oils. Their composition can vary due to factors which affect the plant's environment (e.g. geographical location, soil type, weather conditions, etc.) [1]. Oils with a high phenol content, for instance thyme and clove, have antiseptic properties. The fact of antibiotic resistance may have contributed to the increase of studies focusing on the application of essential oils as potential antibiotic agents against plant and human microorganisms [2$5]$.

Previous studies on the antimicrobial activity of essential oils in vitro described a wide range of assays with different parameters (medium recipes, incubation time, solvents, microorganisms) $[6,7]$, so the results from the assays are very different, sometimes their reliability is questionable. Essential oils are volatile, complex and viscous substances that are insoluble in water, so the common screening methods (disc diffusion, agar absorption) are not appropriate for their antimicrobial testing. Therefore, there is a need for optimized and reproducible assays for assessing the antibacterial effects of these oils [8].

The potential applications of bioautography are summerized in the publication written by Choma [9]. Direct bioautography belongs to a large group of antimicrobial screening 
methods and is based on paper or layer separations [10]. A developed chromatoplate is dipped in the suspension of microorganisms growing in a suitable broth. The plate is incubated and microorganisms grow directly on it. For location and visualization of antibacterial substances, tetrazolium salts are usually used, which are converted by the dehydrogenases of living microorganisms to intensely coloured formazan. The clear inhibiton zones of active components will appear on the plate in comparison to the coloured background [11-16]. In other publications naturally luminescent marine bacterium, $V$. fischeri, and a luminescence gene-tagged plant pathogenic strain, Pseudomonas syringae pv. maculicola were used as bioautographic indicators [14-17]. These bacterial cells constitutively emit bioluminescence that is closely dependent on reductive metabolic activity, so the darker areas (lack of light) on the photo images indicate the location of the inhibition zones.

BioArena was developed by Tyihák et al. [18], which is suitable for the study of the mechanism of antibiotic and/or toxic compounds. The BioArena system integrates the up-to-date methodological and biological results of bioautography with OPLC.

Our preliminary microbiological results showed that the essential oil of thyme, clove, cinnamon bark, tea tree and eucalyptus possessed antibacterial activity against different pathogenic bacteria by disc diffusion method (data were not published). Several literature data refer to the antibacterial effect of these oils [19-23], but in the most cases the activity of the oil components was not determined or the applied microbiological techniques were inappropriate.

Therefore, the present study aimed at the chemical characterization of the essential oils of tea tree [Melaleuca alternifolia (Maiden et Betche) Cheel], clove [Syzygium aromaticum (L.) Merr. et Perry], cinnamon bark (Cinnamomum ceylanicum Nees.), 
thyme (Thymus vulgaris L.) and eucalyptus (Eucalyptus globulus Labill.) and the investigation of antibacterial effect of these oil components by TLC-direct bioautographic method using luminescent bacteria. The chemical composition of the oils was controlled by gas chromatography (GC) and gas chromatography-mass spectrometry (GC-MS). To the best of our knowledge, the present study is the first to investigate the biological activity of the tea tree, eucalyptus, clove and cinnamon bark essential oils using TLC-bioautography with luminescent detection.

\section{Experimental}

\subsection{Chemicals}

Analytical-grade solvents obtained from Spektrum-3D Ltd. were used in all experiments. Thymol, carvacrol, eucalyptol and eugenol were purchased from SigmaAldrich Ltd. (Budapest, Hungary). TLC was performed on aluminium foil backed silica gel $60 \mathrm{~F}_{254}$ TLC plates (Merck, Darmstadt, Germany). The mobile phase for TLC was also prepared from analytical-grade solvents.

\subsection{Essential oil samples}

The essential oils of tea tree [Melaleuca alternifolia (Maiden et Betche) Cheel], eucalyptus (Eucalyptus globulus Labill.), clove [Syzygium aromaticum (L.) Merr. et Perry], cinnamon bark (Cinnamomum ceylanicum Nees.) and thyme (Thymus vulgaris L.) were obtained from a Hungarian drug store chain (Herbaria, Hungary). The quality of these essential oils met the standards described in the $5^{\text {th }}$ edition of the European Pharmacopoeia [24]. 


\subsection{GC-FID and GC-MS analysis of the essential oils}

The five essential oils were analysed using a Fisons GC 8000 gas chromatograph (Carlo Erba, Milano) equipped with a flame ionization detector (FID). An Rt- $\beta$-DEXm (Restek) capillary column (30 m long, $0.25 \mathrm{~mm}$ id., $0.25 \mu \mathrm{m}$ film thickness) was used. Nitrogen (flow rate $6.8 \mathrm{~mL} \mathrm{~min}^{-1}$ ) was the carrier gas. $0.2 \mu \mathrm{L}$ of a $0.25 \%$ solution was injected ( $2 \mu \mathrm{L}$ of essential oil in $1 \mathrm{~mL}$ of chloroform). Splitless injection was done. The temperatures of the injector and detector were 210 and $240^{\circ} \mathrm{C}$, respectively. Oven temperature increased at a rate of $8^{\circ} \mathrm{C} \min ^{-1}$ from 60 to $230^{\circ} \mathrm{C}$, with a final isotherm at $230^{\circ} \mathrm{C}$ for 5 min. Percentage evaluation of compounds was carried out by area normalization, identification of peaks was made by comparison of retention times of standards and co-addition of standards. All measurements were made in duplicate.

In the GC-MS experiments Agilent 6890N GC coupled with 5973N mass selective detector, Chrom Card Server ver. 1.2. equipped with a HP-5MS capillary column, $30 \mathrm{~m}$ long, $0.25 \mathrm{~mm}$ id., $0.25 \mu \mathrm{m}$ film thickness was used. The carrier gas was helium $\left(\mathrm{p}_{\mathrm{He}}\right.$ was $0.20 \mathrm{MPa})$, at $1 \mathrm{~mL} \mathrm{~min}^{-1}$ flow rate; $1 \mu \mathrm{L}\left(2 \mu \mathrm{L} \mathrm{mL}^{-1}\right.$ essential oil in chloroform) was injected at $0.7 \mathrm{mg} \mathrm{mL}^{-1}$ velocity, split type (1:30 split ratio) with an Agilent 7683 autosampler. The temperature of the injector was $280^{\circ} \mathrm{C}$, and the temperature of the transfer line was $275^{\circ} \mathrm{C}$. Oven temperature was programmed initially at $60^{\circ} \mathrm{C}$ for $3 \mathrm{~min}$, then increased at a rate of $8^{\circ} \mathrm{C} \min ^{-1}$ to $200^{\circ} \mathrm{C}$, then kept at $200{ }^{\circ} \mathrm{C}$ for $2 \mathrm{~min}$, before increasing at a rate of $10^{\circ} \mathrm{C} \min ^{-1}$ to $250^{\circ} \mathrm{C}$ with a final isotherm at $250^{\circ} \mathrm{C}$ for $15 \mathrm{~min}$. MS conditions: ionization energy $70 \mathrm{eV}$; mass range $\mathrm{m} / \mathrm{z} 40-500 ; 1$ analysis $\mathrm{min}^{-1}$. Identification of peaks was carried out by comparison with MS and retention data of standards and spectra from the NIST library [25]. These analyses were meant to check 
only the main components and the composition of the essential oils examined in this study.

\subsection{Planar chromatographic separation and detection of essential oils}

TLC was performed on $10 \times 10 \mathrm{~cm}$ aluminium foil backed silica gel $60 \mathrm{~F}_{254}$ plates. Before use the plates were preconditioned by heating at $120^{\circ} \mathrm{C}$ for $3 \mathrm{~h}$. Essential oil samples were dissolved in ethanol to give solutions containing $100 \mu \mathrm{L}$ oil in $5 \mathrm{~mL}$ ethanol, and 0.5 or $1 \mu \mathrm{L}$ of it (equivalent to 0.01 or $0.02 \mu \mathrm{L}$ undiluted oil) were applied to the TLC plate with Minicaps capillary pipettes (Hirschmann Laborgeräte GmbH, Germany). The antibacterial activity of the characteristic components (thymol, carvacrol, and eucalyptol) of the essential oils was also investigated by direct bioautography. Pure samples of these chemicals were dissolved in ethanol to give solutions containing $1 \mathrm{mg} \mathrm{mL}^{-1}$ or $5 \mu \mathrm{L} \mathrm{mL}^{-1}$. From the solution of the standards $1 \mu \mathrm{L}$ was applied to the plates using Minicaps capillary pipettes. The position of the starting line was $1.5 \mathrm{~cm}$ from the bottom and $1 \mathrm{~cm}$ from the left side. The standards were applied to the TLC plates next to the spots of the oils. After sample application, the plates were developed with toluene - ethyl acetate (93:7) [26]. Ascendant development chromatography was used, in a saturated twin trough chamber (Camag, Switzerland). All TLC separations were performed at room temperature $\left(23^{\circ} \mathrm{C}\right)$. Separation distance was $8 \mathrm{~cm}$ and the time was approx. $30 \mathrm{~min}$. After chromatographic separation the absorbent layers were dried under air flow, for 5 min to remove the solvent completely. Ethanolic vanillin - sulfuric acid reagent [26] was used to visualize the separated compounds. The developed layers were dipped into this reagent and heated for $5 \mathrm{~min}$ at $90^{\circ} \mathrm{C}$. Detection of the separated compounds was performed according to $\mathrm{R}_{\mathrm{f}}$ value and 
color of the standards. The TLC plate for bioautography was prepared without visualization with a reagent, because this does not affect the success of the subsequent microbial detection process in bioautography.

\subsection{Direct bioautography}

The antibacterial effect of essential oil components was evaluated in vitro with direct bioautography against the Gram-negative, luminescence tagged, plant pathogenic bacterium Pseudomonas syringae pv. maculicola (Psmlux) [27] and the Gram-negative, naturally luminescent marine bacterium Vibrio fischeri.

Psmlux was grown in King's B broth [28], V. fischeri strain (Lumistox test strain, HachLange Ltd.) in the dark in the following liquid medium (slightly modified recipe of NCAIM, Corvinus University, Budapest; ingredients are expressed in $\mathrm{g} \mathrm{dm}^{-3}$ ): pepton 5, yeast extract 5, meat extract $6, \mathrm{NaCl} 24, \mathrm{MgSO}_{4} 3.4, \mathrm{MgCl}_{2} \times 6 \mathrm{H}_{2} \mathrm{O} 5.3, \mathrm{KCl} 0.7$, and $\mathrm{CaCl}_{2}$ 0.1.

Cultures of Psmlux and $V$. fischeri were well aerated by shaking at $28.5{ }^{\circ} \mathrm{C}$ until they reached an optical density of 1.2 and 2.4 at $600 \mathrm{~nm}$, respectively.

The dried, developed chromatoplates with separated spots were immersed for $10 \mathrm{~s}$ into these bacterial cell suspensions and then put into a transparent glass cage assuring an air phase and humidity for the bacterial cells. The bioluminescent light emission was detected by use of a computer-controlled cooled CCD camera (IS-4000, Alpha Innotech, San Leandro, USA). Two minutes after immersion the chromatoplates were placed under the camera. The exposition time was $5 \mathrm{~min}$ in the case of $V$. fisheri, and 15 min in the case of Psmlux, respectively. The darker areas on the images, where bacterial 
cells do not emit light, indicate the lack of metabolic activity, which in turn depends on viability.

\section{Results and Discussion}

\subsection{Gas Chromatographic Detection}

The quality of the essential oils used in this study was determined by GC. Percentage composition was identified by area normalization on the basis of two parallel measurements. Eucalyptol $(84.2 \%)$ was the main component of the essential oil of eucalyptus, eugenol (83.7\%) of clove oil, and trans-cinnamic aldehyde (73.2\%), thymol $(49.9 \%)$ and terpinen-4-ol $(45.8 \%)$ of cinnamon bark, thyme and tea tree oils, respectively. In the eucalyptus oil $p$-cymene $(7.4 \%)$ and limonene $(4.6 \%)$ were also identified. $\beta$-caryophyllene $(9.3 \%)$ was also presented in the clove oil, limonene $(1.54 \%)$ in cinnamon bark oil, $p$-cymene $(26.5 \%)$ and carvacrol $(1.1 \%)$ in thyme oil, $\gamma$ terpinene $(19.3 \%), p$-cymene $(6.7 \%)$ and $\alpha$-terpinene $(5.8 \%)$ in the tea tree oil, respectively.

\subsection{TLC-Direct Bioautography}

TLC separation of the five essential oils and their components was performed by parallel analysis on $10 \times 10$ TLC plates. After development the plates were cut into halves. One half was dipped into the alcoholic vanillin-sulphuric acid reagent to detect the essential oil components and the other was dipped into the bacterial suspension for bioautographic procedure. Therefore, the chromatographic conditions were the same for both. In the TLC-bioautographic system the antibacterial activity of the components of the five essential oils was determined according to the appearance of the inhibition 
zones (lack of emitted light, dark area). The minor components of the tested essential oils had also apparent activity at the concentration tested.

In the oil of thyme, thymol and carvacrol could be identified as a single red zone at $R_{f}=$ 0.54 (Figure 1c). These compounds showed a visible inhibition zone in the bioautographic system (Figure 1a, b). The standard of thymol and carvacrol showed also antibacterial activity against the two test bacterial strains (Figure 1a, b). At $R_{\mathrm{f}} 0.36$ an inhibition zone was observed in the thyme oil. According to the GC method as well as our earlier results [13] the presence of linalool was supposed.

In the oil of clove, the main component was eugenol (brown zone, $R_{f}=0.49$ ) and a violet zone of $\beta$-caryophyllene could be detected at $\mathrm{R}_{\mathrm{f}}=0.82$ by reference to [26] (Figure 2c). According to gas chromatographic analysis, trans-cinnamic aldehyde $(73.2 \%)$ was the main component in the cinnamon oil and the amount of eugenol was only $2.7 \%$. However, the two compounds could not be separated by TLC when developed with toluene - ethyl acetate (93:7), due to their similar $R_{f}$ values. Cinnamic aldehyde and eugenol (as a brown zone at $\mathrm{R}_{\mathrm{f}}=0.49$ ) were identified by reference to [26]. In the oil of cinnamon, at $R_{\mathrm{f}}$ of trans-cinnamic aldehyde and eugenol, and in the oil of clove eugenol inhibited the growth of both test bacteria (Figure 2a, b). The main components, trans-cinnamic aldehyde and eugenol, produced the largest inhibition zones in these two oils and therefore they may be used as an antibacterial agents, but the effect of minor components should also be taken into consideration. The quantitative difference between thymol (49.9\%) and carvacrol (1.1\%), as well as cinnamic aldehyde $(73.2 \%)$ and eugenol (2.7\%) was significant in thyme and cinnamon oils, respectively. We applied standards of these compounds (thymol and carvacrol) to the plate for comparison. 
In the eucalyptus oil, the main component was eucalyptol (blue zone at $R_{f}=0.49$ ) (Figure 3c). In the oil of tea tree, we could not exactly identify the components without standards. Two blue zones were detected at $\mathrm{R}_{\mathrm{f}}=0.24$ and $\mathrm{R}_{\mathrm{f}}=0.37$. According to ref. [26] and the GC analysis, these compounds can be identified as monoterpene alcohols (terpinen-4-ol and terpineol). In tea tree oil the monoterpene alcohols, $\alpha$-terpineol $\left(\mathrm{R}_{\mathrm{f}}=\right.$ $0.24)$ and terpinen-4-ol $\left(\mathrm{R}_{\mathrm{f}}=0.37\right)$ showed significant antibacterial effects against $V$. fischeri (Figure 3b). In the TLC-bioautographic system, the essential oil of eucalyptus and its main component, eucalyptol, and tea tree oil showed weak activity against the strains tested in this study (Figure 3a, b).

It has to be noted that the solvents (toluene and ethyl acetate) applied in TLC separation as mobile phase components had no inhibiting effect in the direct bioautographic system, however they were eliminated from the layer .

In every case $V$. fischeri was more sensitive bacterium against the essential oil components than Psmlux.

Our results confirmed that the antibacterial activity of the essential oils is associated with their main components, but the minor constituents may also contribute to this effect.

\section{Conclusion}

The results of this study can provide reliable in vitro experimental data for the ability of essential oils as complex, hydrophobic extracts to determine the antibacterial properties of their components. The essential oil components of tea tree [Melaleuca alternifolia (Maiden et Betche) Cheel], eucalyptus (Eucalyptus globulus Labill.), clove [Syzygium aromaticum (L.) Merr. et Perry], cinnamon bark (Cinnamomum ceylanicum Nees.) and 
thyme (Thymus vulgaris L.) were investigated by TLC-bioautography using luminescent bacteria. Besides the main components of the oils such as terpinen-4-ol, eucalyptol, eugenol, trans-cinnamic aldehyde and thymol, monoterpene alcohols as minor components also possessed antibacterial effect. Trans-cinnamic aldehyde and eugenol were the most active compounds in TLC-bioautographic system used in this study. The components of eucalyptus and tea tree oils showed less activity against Psmlux and $V$. fisheri. The mechanism of antibacterial action of essential oils has not yet really understood, but the studies focusing on this field has been increasing [29-31]. The knowledge about the cell target(s) of the essential oils and their components is crucial to understand their role in the process of antibacterial activity. This biological effect of these plant materials is linked to their hydrophobicity resulting in increased cell permeability and consequent leaking of cell constituents, but the interaction between the oil components should be also considered.

Without doubt direct bioautography has an expanding field of application and practical advantage in research on antibiotic substances having natural origin. To exploit the phenomenon of bioluminescence in TLC-bioautography the antibacterial activity of individual essential oil components can be detected.

With investigation of antimicrobial activity of the essential oils a suggestion for their application as antibacterial agents may be presented. Further studies need to focus on modelling the mode of antibacterial mechanisms of essential oil components.

\section{Acknowledgements}

The authors thank to Jun Fan (John Innes Center, Department of Disease and Stress Biology, Norwich, UK) for luminescent Pseudomonas syringae pv. maculicola. This 
work was partially supported by OTKA grant no. PD83487 and K101271 and Á.M. Móricz was supported by Bolyai grant.

\section{References}

[1] C. Franz, and J. Novak, in: K.H. Can Baser and G. Buchbauer (Eds.) Handbook of Essential Oils. Science, Technology, and Applications, CRC Press, USA, 2010, pp. $39-81$.

[2] C. Rota, J.J. Carramiñana, J. Burillo, and A. Herrera, J. Food Prot. 67 (2004) 12521256.

[3] A.P.L. Delamare, I.T. Moschen-Pistorello, L. Artico, L. Atti-Serafini, and S. Echeverrigaray, Food Chem. 100 (2007) 603-608.

[4] F.F.G. Rodrigues, J.G.M. Costa, and H.D.M. Coutinho, Phytomedicine 16 (2009) $1052-1055$.

[5] R. Tserennadmid, M. Takó, L. Galgóczy, T. Papp, M. Pesti, Cs. Vágvölgyi, K. Almássy, and J. Krisch, Int. J. Food. Microbiol. 144 (2010) 480-486.

[6] S.G. Griffin, S.G. Wyllie, J.L. Markham, and D.N. Leach, Flav. Fragr. J. 14 (1999) $322-332$.

[7] S. Inouye, H. Yamaguchi, and T. Takizawa, J. Infect. Chemother. 7 (2001) 251-254.

[8] J.R. Hood, J.M. Wilkinson and H.M.A. Cavanagh, J. Essent. Oil Res. 15(6) (2003) $428-433$

[9] I.M. Choma, E.M. Grzelak, J. Chromatogr. A 1218 (2011) 2684-2691.

[10] L. Botz, S. Nagy, and B. Kocsis, in: Sz. Nyiredy (Ed.) Planar Chromatography, Springer, Budapest, 2001, pp. 489-516.

[11] W.J. Begue, and R.M. Kline, J. Chromatogr. 64 (1972) 182-184.

[12] M.O. Hamburger, and G.A. Cordell, J. Nat. Prod. 50 (1987) 19-22. 
[13] Gy. Horváth, L. Botz, B. Kocsis, É. Lemberkovics, and L.GY. Szabó, Acta Bot. Hung. 46 (2004) 153-165.

[14] Á.M. Móricz, Gy. Horváth, P. Molnár, B. Kocsis, A. Böszörményi, É. Lemberkovics, and P.G. Ott, J. Planar Chromatogr. 23(6) (2010) 406-410.

[15] Á.M. Móricz, E. Tyihák, and P.G. Ott, J. Planar Chromatogr. 23(3) (2010) 180-183

[16] Á.M. Móricz, P.G. Ott, A. Böszörményi, É. Lemberkovics, E. Mincsovics, and E. Tyihák, Chromatographia 75 (2012) 991-999.

[17] Á.M. Móricz, Sz. Szarka, P.G. Ott, D. Kertesy, É.B. Héhelyi, É. Szőke, and E. Tyihák, J. Planar Chromatogr. 25(3) (2012) 220-224.

[18] E. Tyihák, Á.M. Móricz, and P.G. Ott, J. Planar Chromatogr. 21 (2008) 77.

[19] I. Rasooli, M.B. Rezaei, and A. Allameh, Int. J. Infect. Dis. 10 (2006) 236-241.

[20] P. Gońi, P. López, C. Sánchez, R. Gómez-Lus, R. Becerril, and C. Nerín, Food Chem. 116 (2009) 982-989.

[21] L. Fei, D.Yi-cheng, Y. Xing-qian, and D. Yu-ting, Agric. Sci. China 10(9) (2011) $1482-1487$.

[22] M. D’Arrigo, G. Ginestra, G. Mandalari, P.M. Furneri, and G. Bisignano, Phytomedicine 17 (2010) 317-322.

[23] A. Elaissi, K.H. Salah, S. Mabrouk, K.M. Larbi, R. Chemli, and F. Harzallah-Skhir, Food Chem. 129 (2011) 1427-1434.

[24] European Pharmacopoeia, $5^{\text {th }}$ edn, European Directorate for the Quality of Medicines (EDQM), Strasbourg, 2004, pp. 1295, 1335, 1570, 2534, 2569.

[25] R.P. Adams, Identification of essential oil components by gas chromatography/quadrupole mass spectrometry $4^{\text {th }}$ ed., Allured Publishing, Carol Stream, Illinois, USA, 2001. 
[26] H. Wagner, and S. Bladt, Plant drug analysis. A thin layer chromatography atlas $2^{\text {nd }}$ ed., Springer, Berlin, Heidelberg, New York, 2001.

[27] J. Fan, C. Crooks, and C. Lamb, Plant J. 53 (2008) 393-399.

[28] E.O. King, M.K. Ward, and D.E. Raney, J. Lab. Clin. Med. 44 (1954) 301-307.

[29] H.J.D. Dorman and S.G. Deans, J. Appl. Microbiol. 88 (2000) 308-316.

[30] S.A. Burt, R.V. Der Zee, A.P. Koets, A.M. De Graaff, F. van Knapen, W. Gaastra, H.P. Haagsmann, and E.J.A. Veldhuizen, Appl. Environ. Microbiol. 73 (2007) 4484-4490.

[31] R.J.W. Lambert, P.N. Skandamis, P.J. Coote, and G.J.E. Nychas, J. Appl. Microbiol. 91 (2001) 453-462. 
a

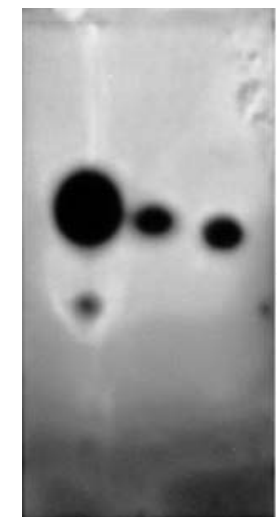

$\begin{array}{lll}1 & 2 & 3\end{array}$ b

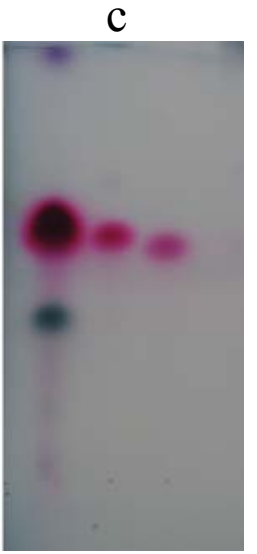

\section{Figure 1}

Antibacterial effect of thyme (Thymus vulgaris L.) essential oil and its components against (a) Pseudomonas syringae pv. maculicola and (b) Vibrio fischeri bacteria; and (c) the developed layer after vanillin-sulphuric acid detection. $1-1 \mu \mathrm{L}$ of thyme essential oil (equivalent to $0.02 \mu \mathrm{L}$ undiluted oil); $2-1 \mu \mathrm{L}$ of thymol standard (equivalent to $1 \mu \mathrm{g}$ of thymol); $3-1 \mu \mathrm{L}$ of carvacrol standard (equivalent to $0.005 \mu \mathrm{L}$ of carvacrol).

a

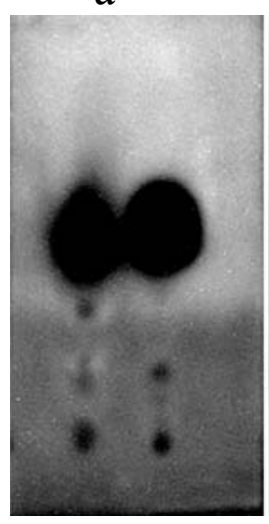

12 b

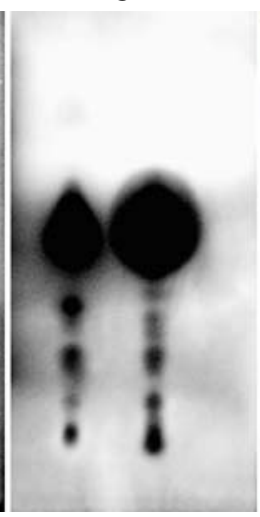

$\mathrm{c}$

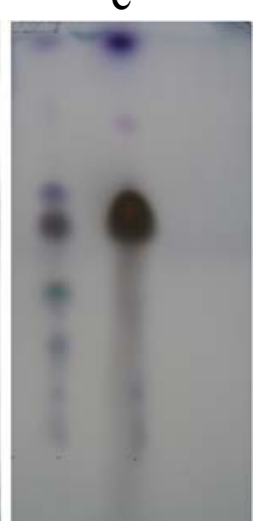

\section{Figure 2}

Antibacterial effect of components of cinnamon bark (Cinnamomum ceylanicum Nees.) and clove [Syzygium aromaticum (L.) Merr. et Perry] essential oils against (a) Pseudomonas syringae pv. maculicola and (b) Vibrio fischeri bacteria; and (c) the developed layer after vanillin-sulphuric acid detection. $1-0.5 \mu \mathrm{L}$ of cinnamon bark essential oil (equivalent to $0.01 \mu \mathrm{L}$ undiluted oil); $2-0.5 \mu \mathrm{L}$ of clove oil (equivalent to $0.01 \mu \mathrm{L}$ undiluted oil). 
a

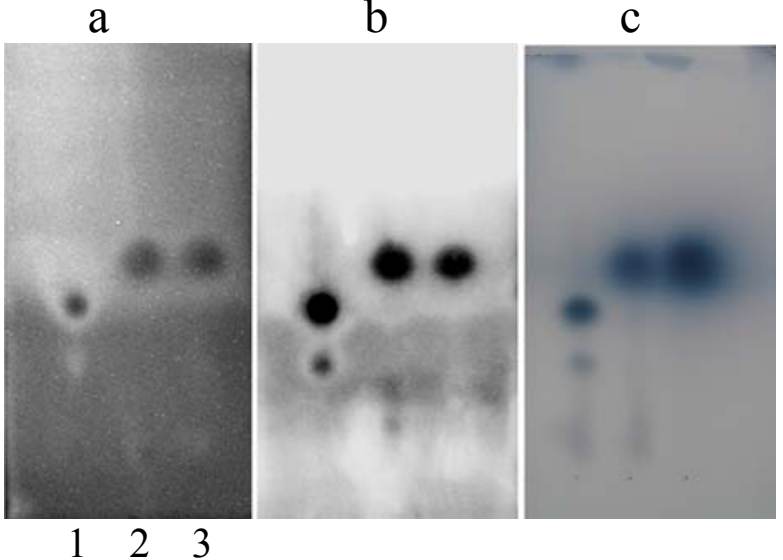

Figure 3

Antibacterial effect of components of tea tree [Melaleuca alternifolia (Maiden et Betche) Cheel] and eucalyptus (Eucalyptus globulus Labill.) essential oil against (a) Pseudomonas syringae pv. maculicola and (b) Vibrio fischeri bacteria; and (c) the developed layer after vanillin-sulphuric acid detection. $1-1 \mu \mathrm{L}$ of tea tree essential oil (equivalent to $0.02 \mu \mathrm{L}$ undiluted oil); $2-1 \mu \mathrm{L}$ of eucalyptus essential oil (equivalent to $0.02 \mu \mathrm{L}$ undiluted oil); $3-1 \mu \mathrm{L}$ of eucalyptol standard (equivalent to $0.005 \mu \mathrm{L}$ of eucalyptol). 